Tropical Journal of Pharmaceutical Research March 2017; 16 (3): 589-595

ISSN: $1596-5996$ (print); 1596-9827 (electronic)

(C) Pharmacotherapy Group, Faculty of Pharmacy, University of Benin, Benin City, 300001 Nigeria.

All rights reserved.

Available online at http://www.tjpr.org

Original Research Article

http://dx.doi.org/10.4314/tjpr.v16i3.13

\title{
Therapeutic effect of Lianbeijuqin (a Chinese herbal cocktail) on periodontitis in rat
}

\author{
Jie Zhang and Xiao-Ming Shi* \\ Department of Stomatology, Linyi People's Hospital, Linyi, Shangdong, 276003, China
}

${ }^{*}$ For correspondence: Email: shixmsd@126.com

Received: 22 November 2016

Revised accepted: 15 February 2017

\begin{abstract}
Purpose: To investigate the therapeutic effect of Lianbeijuqin (LBJQ) decoction on periodontitis in rats in vivo and in vitro.

Methods: High performance liquid chromatography (HPLC) was used to analyze the main constituents of LBJQ. Periodontitis in rats was induced in rats by ligation with bacteria-infected silk. Gingival index (GI) and attachment loss (AL) were evaluated. Additionally, the antibacterial activity of LBJQ against Porphyromonas gingivalis, Prevotella intermedius, Actinobacillus actinomycetemcomitans, Fusobacterium nucleatum, Streptococcus sanguis and Streptococcus mutans were evaluated using minimal inhibitory concentration (MIC) and minimal bactericidal concentration (MBC) values. Furthermore, the inhibitory effect of LBJQ on the release of TNF- $\alpha, I L-1 \beta$ and IL- 6 was also determined. Results: HPLC revealed the presence of phellodendrine, baicalin, palmatine, berberine, baicalein, wogonin and obacunone in LBJQ. LBJQ decoction dose-dependently (200, 400 and $800 \mathrm{mg} / \mathrm{kg}$ ) and significantly decreased $G I$ and $A L(p<0.05)$ in the periodontitis model rats. It also exerted significant antibacterial effect against P. gingivalis (MIC, $0.64 \mathrm{mg} / \mathrm{mL} ; M B C, 2.56 \mathrm{mg} / \mathrm{mL}$ ), P. intermedius (MIC, $0.32 \mathrm{mg} / \mathrm{m} ; \mathrm{MBC}, 2.56 \mathrm{mg} / \mathrm{mL}$ ), A. actinomycetemcomitans (MIC, $1.28 \mathrm{mg} / \mathrm{mL} ; \mathrm{MBC}, 5.12 \mathrm{mg} / \mathrm{mL}$ ), $F$. nucleatum (MIC, $0.16 \mathrm{mg} / \mathrm{mL}$; MBC, $0.64 \mathrm{mg} / \mathrm{mL}$ ), S. sanguis (MIC, $0.64 \mathrm{mg} / \mathrm{mL} ; M B C, 5.12 \mathrm{mg} / \mathrm{mL}$ ), and S. mutans (MIC, $0.16 \mathrm{mg} / \mathrm{mL} ; M B C, 1.28 \mathrm{mg} / \mathrm{mL}$ ). Moreover, LBJQ decoction dose-dependently and significantly decreased the release of TNF- $\alpha(p<0.01), I L-1 \beta(p<0.01)$ and IL-6 $(p<0.01)$ in LPSinduced RAW 264.7 cells.

Conclusion: $L B J Q$ exerts therapeutic activity against periodontitis in rats via inhibition of the release of inflammatory cytokines and growth of oral anaerobic bacteria.
\end{abstract}

Keywords: Lianbeijuqin decoction, Periodontitis, Phellodendrine, Baicalin, Palmatine, Berberine, Porphyromonas gingivalis, Prevotella intermedius, Inflammatory cytokines

Tropical Journal of Pharmaceutical Research is indexed by Science Citation Index (SciSearch), Scopus, International Pharmaceutical Abstract, Chemical Abstracts, Embase, Index Copernicus, EBSCO, African Index Medicus, JournalSeek, Journal Citation Reports/Science Edition, Directory of Open Access Journals (DOAJ), African Journal Online, Bioline International, Open-J-Gate and Pharmacy Abstracts

\section{INTRODUCTION}

Periodontitis is a chronic oral inflammatory disorder that occurs in tooth-supporting tissues such as gingiva and radices dentis. It results in significant damage to surrounding tissue structures, leading to loss of teeth [1,2]. Besides tooth loss, periodontitis is associated with other discomforts such as gomphiasis, swelling and aching of gum, fever and bromopnea [3,4].
Current treatment and periodontal tissue regeneration strategies for periodontitis involve scaling, root planning and regenerative surgeries $[5,6]$. However, strategies for radical treatment of periodontitis are still limited [7].

Lianbeijuqin (LBJQ) decoction is prepared from a Chinese herbal formula which consists of 7 herbal medicines (Table 1). In Chinese traditional medicinal theory system, LBJQ is used for 
clearing heat, drying dampness and for clinical treatment of chronic periodontitis. However, although LBJQ is a traditionally used Chinese formula for periodontitis treatment, its therapeutic effects and pharmacological mechanisms of action are still not clear.

This study was carried out to evaluate the therapeutic effect of $L B J Q$ in a rat model of periodontitis. In addition, the anti-bacterial effects of LBJQ on common oral pathogenic bacteria, and its inhibitory effects on the release of proinflammatory cytokines in LPS-treated RAW 264.7 cells were determined, with a view to unraveling its mechanism of action.

\section{EXPERIMENTAL}

\section{Chemicals and reagents}

Dulbecco's modified eagle medium (DMEM) and fetal bovine serum (FBS) were purchased from the Gibco Biotech. (Carlsbad, USA), lipopolysaccharide (LPS) and 3-(4, 5dimethylthiazol-2-yl)-2, 5-diphenyltetrazolium bromide (MTT) were obtained from Sigma Co. (Shanghai, China). Tumor necrosis factor (TNF$\alpha$ ), interleukin (IL)- $\beta$ and IL- 6 ELISA kits were purchased from the Wuhan CUSABIO Biotech. (Wuhan, China); standards (phellodendrine, ferulic acid, baicalin, palmatine, berberine, baicalein, wogonin and obacunone) were obtained from the NICPBP (Beijing, China).

\section{Animals}

Sprague Dawley (SD) rats $(260 \sim 280 \mathrm{~g})$ were got from Shanghai Laboratory Animal Research Center (Shanghai, China). The rats were kept in a humidity/temperature-controlled room and allowed ad libitum access to food and water. The animal experimental protocols were performed according to the National Institute of Health Guide for the Care and Use of Laboratory Animals [8], and were approved by the Animal Care and Use Committee of the Linyi People's Hospital (Linyi, China) (no. 1504A02).

\section{Cell culture}

The RAW264.7 cell line, a murine macrophage cell line, was purchased from the American Type Culture Collection (ATCC, Rockville, USA). RAW264.7 cells were cultured in DMEM containing $10 \%$ FBS in a $\mathrm{CO}_{2}$ incubator (5\% $\left.\mathrm{CO}_{2}, 37^{\circ} \mathrm{C}\right)$.

\section{Preparation of aqueous extracts of LBJQ}

Aqueous decocting is the primary method for preparation of LBJQ in folk medicine. The herbal contents of LBJQ were ground and extracted 6 times with water. Each extraction lasted for 30. The pooled extract was filtered, and the clear filtrate was concentrated under in vacuum under $50{ }^{\circ} \mathrm{C}$ with a rotary evaporator to yield the LBJQ aqueous extract (yield of LBJQ was $12.73 \%$ ).

\section{HPLC analysis of LBJQ}

The constituents of the extract were determined with HPLC using a gradient elution with a CAPCELL PAK MG II S5 $\mathrm{C}_{18}$ column $(250 \mathrm{~mm} \times$ $4.6 \mathrm{~mm}, 5 \mu \mathrm{m}$ ) (Shiseido, Japan).The mobile phase consisted of acetonitrile (solvent $A$ ) and $0.1 \%$ phosphoric acid-water solution (solvent B, containing $0.02 \mathrm{M}$ sodium phosphate monobasic), and the gradient program was $10 \%$ A (0 - $10 \mathrm{~min}) ; 20$ - $40 \%$ A (10 - $30 \mathrm{~min}) ; 40$ - 60 $\%$ A (20 - $40 \mathrm{~min}) ; 40$ - $60 \mathrm{~min}(40-60 \% \mathrm{~A})$; and $60-80 \%$ A (40 - $60 \mathrm{~min})$. The mobile flow rate was set at $1.0 \mathrm{~mL} / \mathrm{min}$, and the detection wavelength was at $215 \mathrm{~nm}$. The column temperature and sample injection volume were $30{ }^{\circ} \mathrm{C}$ and $10.0 \mu \mathrm{L}$, respectively.

\section{Determination of therapeutic effect of LBJQ on rat periodontitis}

Dental plaque bacteria were isolated from definite diagnosed periodontitis patients in the Linyi People's Hospital, Linyi, China, and then diluted with normal saline.

Table 1: Composition of $L B J Q$

\begin{tabular}{|c|c|c|c|}
\hline Name & Plant origin & Part & Content (g) \\
\hline Coptidis Rhizoma & Coptis chinensis Franch & Roots & 10 \\
\hline Galla Chinensis & Melaphis chinensis (Bell) Baker & Insect gall & 12 \\
\hline Chrysanthemi Indici Flos & Chrysanthemum indicum L. & Flowers & 15 \\
\hline Scutellariae Radix & Scutellaria baicalensis Georgi & Roots & 10 \\
\hline Rhei Radix et Rhizoma & Rheum palmatum $\mathrm{L}$ & Roots & 8 \\
\hline Phellodendri Chinensis Cortex & $\begin{array}{l}\text { Phellodendrom chinense } \\
\text { Schneid }\end{array}$ & Cortex & 10 \\
\hline Glycyrrhizae Radix et Rhizoma & Glycyrrhiza uralensis Fisch. & Roots & 5 \\
\hline
\end{tabular}


Subsequently, the diluted dental bacteria were inoculated in anaerobic blood agar plate with sterile $5-0$ silks for 5 days at $37^{\circ} \mathrm{C}$. Thereafter, the dental bacteria-infected silks were ligatured around the maxillary first molar on the left side of rats under anesthesia (pentobarbital sodium, 45 $\mathrm{mg} / \mathrm{kg}, i p$ ). The ligatures were removed 21 days after the ligature surgery. For normal (sham) rats, the same surgical protocol was given but with sterile 5-0 silks instead of dental bacteria infected 5-0 silks.

The periodontitis model rats were divided randomly into 4 for groups $(n=10)$ : control and 3 LBJQ treatments groups (200, 400 and 800 $\mathrm{mg} / \mathrm{kg}$ ). In addition, another set of 10 rats were treated as normal group. Rats in LBJQ treatments groups were orally administered LBJQ (200, 400 and $800 \mathrm{mg} / \mathrm{kg}$, po), while rats in normal and control groups were orally given normal saline $(10 \mathrm{~mL} / \mathrm{kg}, p o)$. At $4,6,8$ and 10 weeks after ligature surgery, the rats were anesthetized with pentobarbital sodium (45 $\mathrm{mg} / \mathrm{kg}$, ip). Then gingival index (Gl) and attachment loss $(A L)$ were evaluated according to standard methods $[9,10]$. The $\mathrm{Gl}$ was classified as follows: 0 (healthy gingiva; 1 (mild inflammation, i.e. mild change in gingiva color, and /or mild edema without bleeding); 2 (moderate inflammation i.e. redness in gingiva, severe edema and bleeding) and 3 (severe inflammation, i.e., visibly red and swollen; ulcerous and bleeding). Four detecting points, namely papillae gingiva, buccal margin, palatine papillae and marginal gingiva of each experimental tooth were determined, and the mean score of the four points was taken as the GI value. Furthermore, a periodontal probe was used to detect the distance between the enamelcement junction and pocket bottom.

\section{Antibacterial tests}

The antibacterial activities of LBJQ against a number of oral pathogenic bacteria were determined. The oral bacteria were $P$. gingivalis (ATCC 33277), P. intermedius (ATCC25361), A. actinomycetemcomitans (ATCC29522), $F$. nucleatum (ATCC 23276), S. sanguis (ATCC 6715) and S. mutans (ATCC 25175). The antibacterial effects of LBJQ were measured via evaluation of MICs and MBCs according to established methods [11, 12]. The final concentrations of LBJQ in bacterial culture medium were $10.24,5.12,2.56,1.28,0.64,0.32$, $0.16,0.08$ and $0.04 \mathrm{mg} / \mathrm{mL}$. The lowest LBJQ concentration which inhibited visible bacterial growth after $24 \mathrm{~h}$ incubation at $37{ }^{\circ} \mathrm{C}$ was considered as the MIC. In the evaluation of MBC, $0.01 \mathrm{~mL}$ bacterial culture medium after the MIC was inoculated on an agar plates for growth another $24 \mathrm{~h}$ at $37^{\circ} \mathrm{C}$, and MBC is the lowest concentration of LBJQ without visible bacterial growth.

\section{Effects of LBJQ on release of pro- inflammatory cytokines in RAW 264.7 cells}

Cells $\left(1.5 \times 10^{6}\right)$ were seeded in a 48 -well plate and cultured for $4 \mathrm{~h}$. Then, the cells were incubated separately with different concentrations of LBJQ (200, 400 and 800 $\mu \mathrm{g} / \mathrm{mL})$ and LPS $(100 \mathrm{ng} / \mathrm{mL})$ for another $8 \mathrm{~h}$. Finally, the culture media were collected for assay of TNF- $\alpha$, IL- $1 \beta$ and IL- 6 with commercial ELISA kits.

\section{Statistical analysis}

Data are expressed as mean \pm standard deviation (SD, $\mathrm{n}=10)$. Differences in means between two groups were analyzed with twotailed Student's $t$-test and were considered statistically significant at $p<0.05$.

\section{RESULTS}

\section{LBJQ composition}

HPLC was used for the qualitative analysis of the constituents of LBJQ. As shown in Figure 1, seven (7) major compounds were identified based on their chromatographic behaviors relative to standards. These compounds were phellodendrine (1), baicalin (2), palmatine (3), berberine (4), baicalein (5), wogonin (6) and obacunone (7).

\section{Therapeutic effect of LBJQ}

Results showed that after the ligature surgery, GI was significantly increased at all the detecting time points relative to rats in normal group $(p<$ 0.01 , Figure 2). However, after 4-week treatment, LBJQ $(400$ and $800 \mathrm{mg} / \mathrm{kg})$ significantly decreased Gl $(p<0.05, p<0.01)$ in the periodontitis model rats, compared to rats in control group. Interestingly, after 6 weeks' treatment (including at 6, 8 and 10 weeks), LBJQ $(200,400$ and $800 \mathrm{mg} / \mathrm{kg})$ significantly and dosedependently decreased Gl $(p<0.01)$ when compared to control rats.

In the periodontitis model rats, SAL was significantly increased when compared with normal rats $(p<0.01)$. However, the 4-week treatment with LBJQ (400 and $800 \mathrm{mg} / \mathrm{kg}$ ) led to significant decreases in AL $(p<0.05)$, relative to control rats. At the end of 6-week treatment, LBJQ brought about significant and dose- 
dependent decreases in $\mathrm{AL}(p<0.01, p<0.05)$ when compared with rats in the control group (Figure 3).

\section{Antibacterial activity}

As shown in Table 2, LBJQ produced significant antibacterial activities against all the tested bacterial strains ( $P$. gingivalis, $P$. intermedius, $A$. actinomycetemcomitans, F.nucleatum, $S$ sanguis and $S$. mutans), with MIC values below 2 $\mathrm{mg} / \mathrm{mL}$ (the MICs were $0.64,0.32,1.28,0.16$, 0.64 and $0.16 \mathrm{mg} / \mathrm{mL}$, respectively). The MBC values were less than $6 \mathrm{mg} / \mathrm{mL}$ (MICs were 2.56 ,
2.56, 5.12, $0.64, \quad 5.12$ and $1.28 \mathrm{mg} / \mathrm{mL}$, respectively).

\section{Effect of LBJQ on release of pro- inflammatory cytokines}

After LPS treatment, there were significant increases in the release of pro-inflammatory cytokines (TNF- $\alpha$, IL-1 $\beta$ and IL-6) from RAW 264.7 cells $(p<0.01$, Figure 4$)$. However LBJQ exposure led to significant and dose-dependent decreases in the levels of these cytokines $(p<$ 0.01 ).

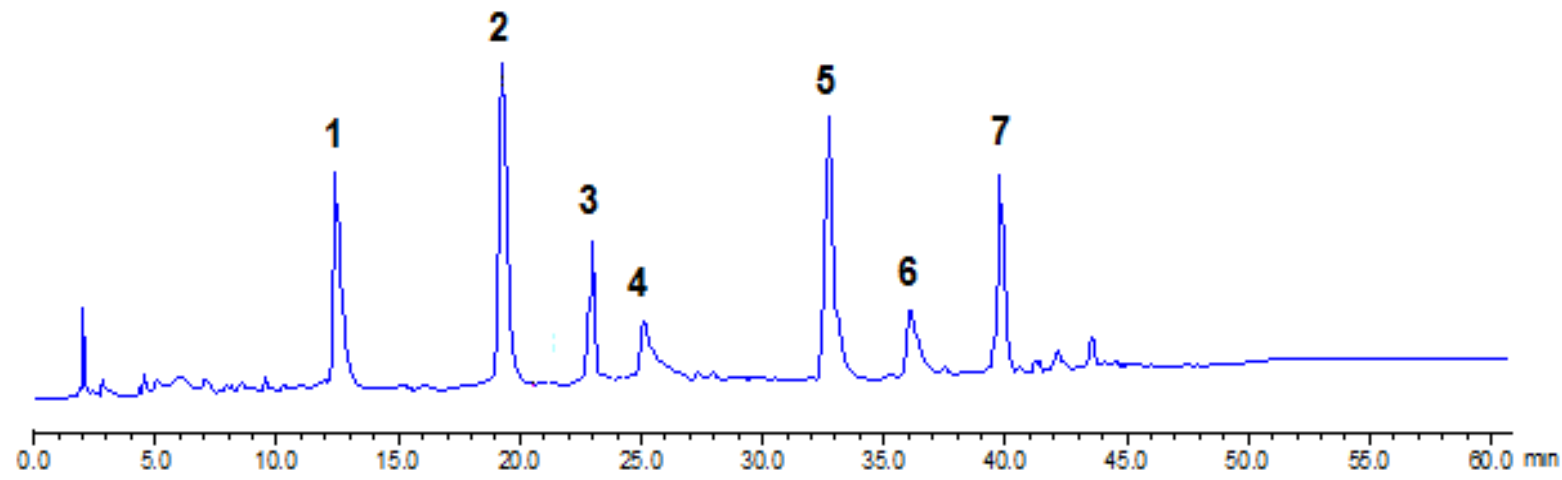

Figure 1: HPLC analysis of the LBJQ. 1-7 represented the phellodendrine (1), baicalin (2), palmatine (3), berberine (4), baicalein (5), wogonin (6) and obacunone (7), respectively
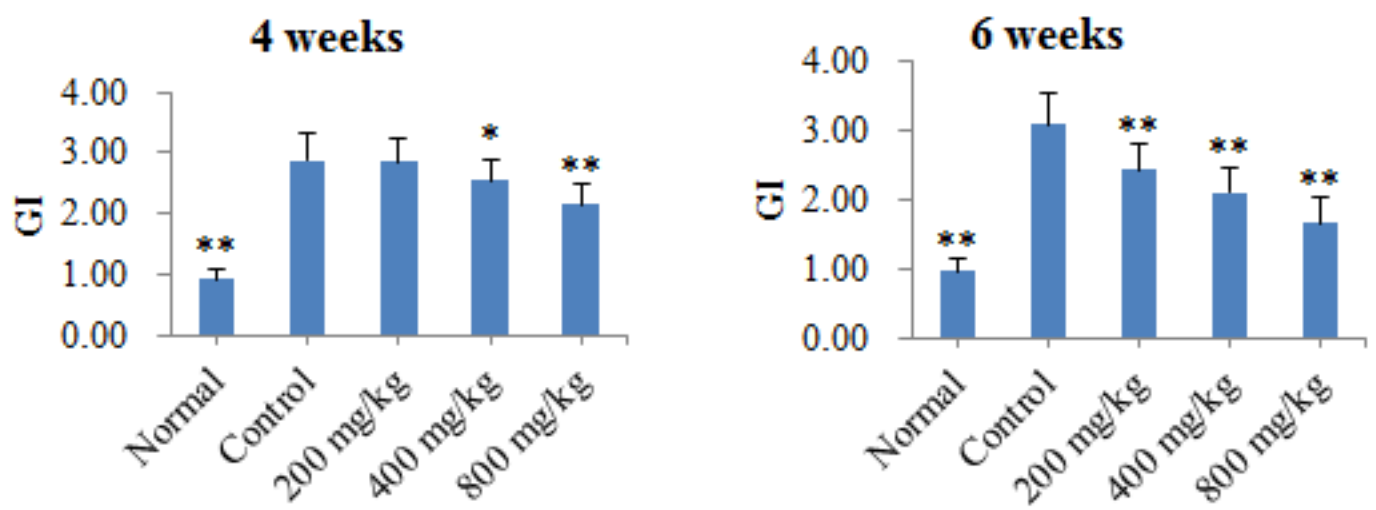

8 weeks

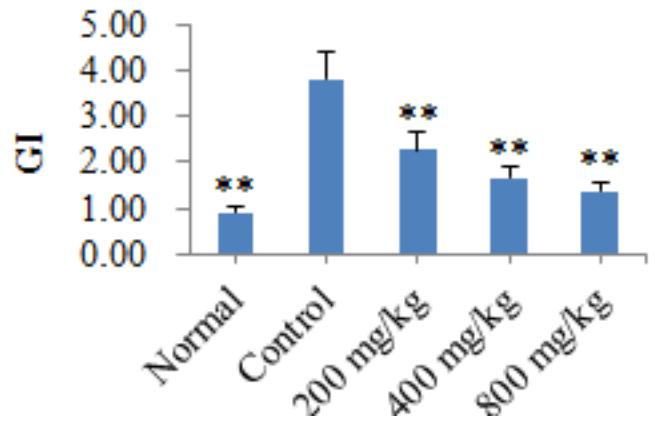

10 weeks

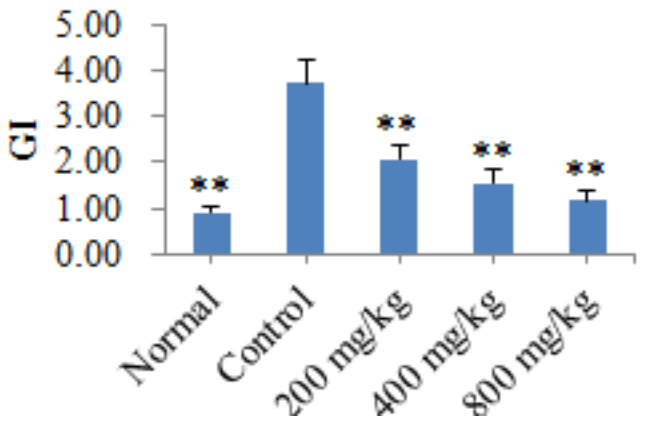

Figure 2: Effect of $L B J Q$ on GI of periodontitis rats. Data are represented as mean $\pm \mathrm{SD}(\mathrm{n}=10) ;{ }^{*} p<0.05,{ }^{* *} p<$ 0.01 , compared to rats in control group 
4 weeks

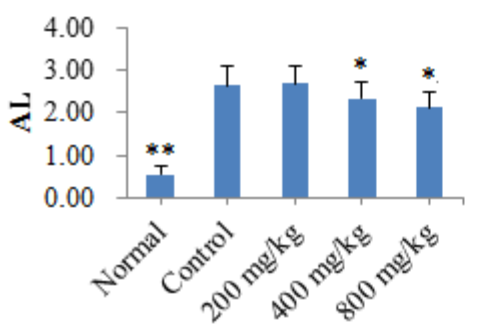

8 weeks

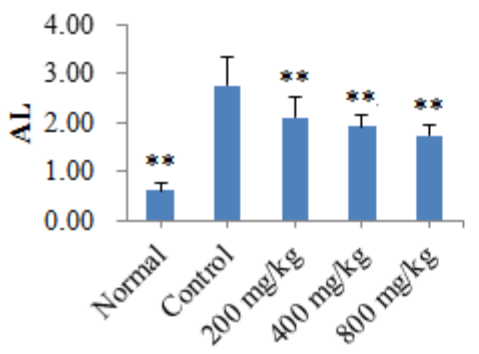

6 weeks

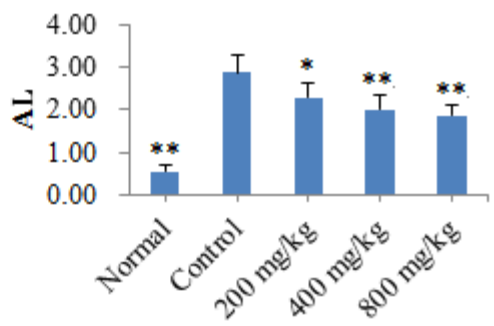

10 weeks

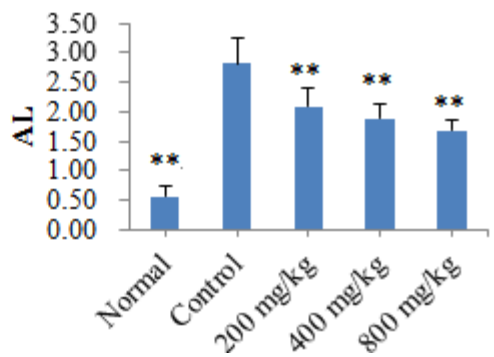

Figure 3: Effect of $L B J Q$ on $A L$ of periodontitis rats. Data are represented as mean $\pm \mathrm{SD}(\mathrm{n}=10) ;{ }^{*} p<0.05,{ }^{* *} p$ $<0.01$, compared to rats in control group

Table 2: Anti-bacterial activity of $L B J Q$

\begin{tabular}{llcc}
\hline \multirow{2}{*}{ Bacterial species } & & \multicolumn{2}{c}{ Concentration $(\mathbf{m g} / \mathbf{m L})$} \\
\cline { 3 - 4 } & & MIC & MBC \\
\hline Porphyromonas gingivalis & ATCC 33277 & 0.64 & 2.56 \\
Prevotella intermedius & ATCC 25361 & 0.32 & 2.56 \\
Actinobacillus actinomycetemcomitans & ATCC 29522 & 1.28 & 5.12 \\
Fusobacterium nucleatum & ATCC 23276 & 0.16 & 0.64 \\
Streptococcus sanguis & ATCC 6715 & 0.64 & 5.12 \\
Streptococcus mutans & ATCC 25175 & 0.16 & 1.28 \\
\hline
\end{tabular}
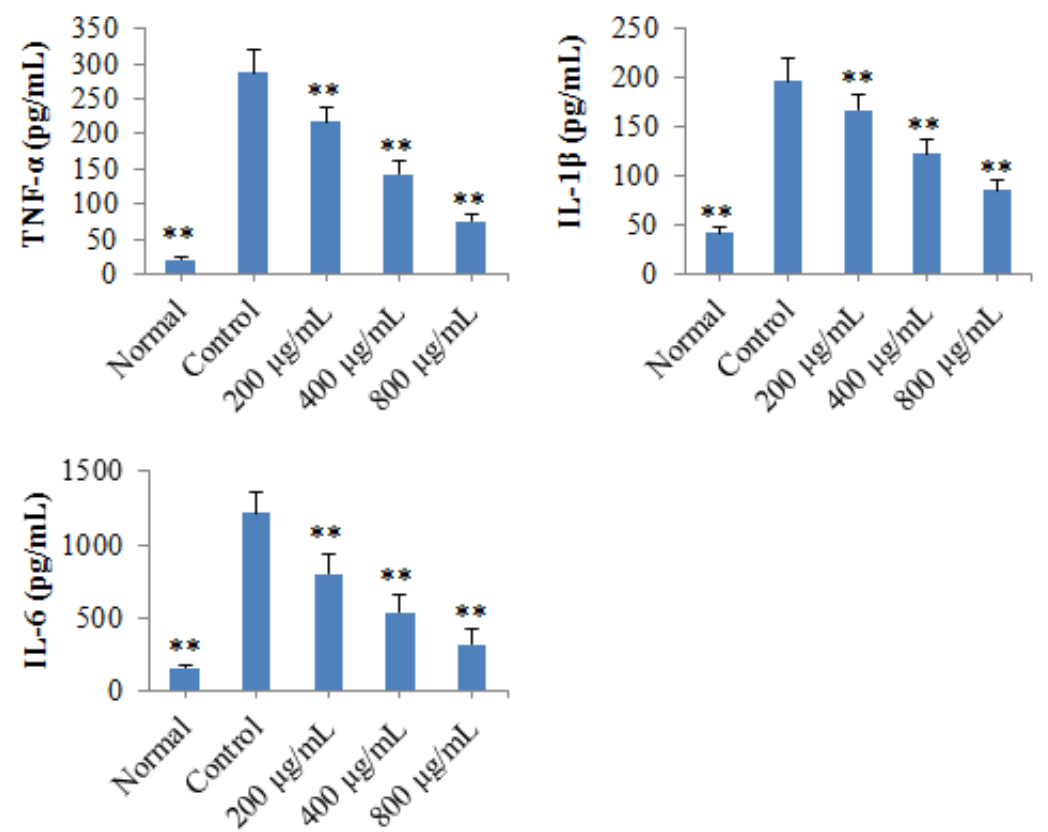

Figure 4: Effects of $L B J Q$ on the releases of inflammatory cytokines induced by LPS in RAW 26.7 cells. Data are represented as mean $\pm \mathrm{SD}(\mathrm{n}=10) ;{ }^{*} p<0.05,{ }^{\star *} p<0.01$, compared to rats in control group. 


\section{DISCUSSION}

Induction of periodontitis in rat model with dental bacteria-infected silk ligation is a standard experimental model for investigating therapeutic activities of candidate drugs against periodontitis $[13,14]$. The results of this study demonstrate for the first time, that LBJQ has potential therapeutic effect against experimental periodontitis in rats.

In recent years, studies have revealed that the pathogenesis of periodontitis is closely related to dental plaque bacteria and their metabolic products which induce local inflammatory reactions in pre-disposed hosts [15]. Thus, the search for more effective agents for suppression of microbial invasion, control of inflammation and protection of periodontal tissue are the primary objectives of periodontitis treatment $[4,17]$. The results of the current research revealed that LBJQ, an age-old Chinese herbal medicine formula, could significantly inhibit the growth of common oral pathogenic bacteria such as $P$. gingivalis, $P$. intermedius, $A$. actinomycetemcomitans, $F$. nucleatum, $S$. sanguis and $S$. mutans.

Pro-inflammatory cytokines play important roles in the development of periodontitis. Inflammatory response leads to leukocyte infiltration, edema, vascular dilatation and release of excess inflammatory cytokines, resulting in detachment of connective tissue, formation of periodontal pocket and resorption of alveolar bone and ultimately tooth loss $[18,19]$. Previous investigations revealed that some early-response pro-inflammatory cytokines such as TNF- $\alpha$, IL-6 and IL-1 $\beta$ are released in response to external stimuli or tissue injury [20]. However, excessive levels of these pro-inflammatory cytokines activate inflammatory reaction cascades, thereby aggravating the inflammatory response that results in periodontitis $[18,20]$. It is also known that excess release of these pro-inflammatory cytokines induce damage to bone tissues of the teeth $[2,21,22]$. The results of this work demonstrate that LBJQ significantly decreased the releases of TNF- $\alpha$, IL- $1 \beta$ and IL- 6 , which might be one of the potential mechanisms through which it exerts its therapeutic effect.

\section{CONCLUSION}

The findings of this study reveal that LBJQ possesses potential therapeutic effects against periodontitis in vivo and in vitro. The probable mechanism may be related to its inhibitory effects on release of inflammatory cytokines and its antibacterial activity against oral anaerobic bacteria. This finding may provide a basis for development of a new and effective drug from LBJQ for clinical treatment of periodontitis.

\section{DECLARATIONS}

\section{Conflict of Interest}

No conflict of interest associated with this work.

\section{Contribution of Authors}

The authors declare that this work was done by the authors named in this article and all liabilities pertaining to claims relating to the content of this article will be borne by them.

\section{Open Access}

This is an Open Access article that uses a funding model which does not charge readers or their institutions for access and distributed under the terms of the Creative Commons Attribution License (http://creativecommons.org/licenses/by 14.0) and the Budapest Open Access Initiative (http://www.budapestopenaccessinitiative.org/rea d), which permit unrestricted use, distribution, and reproduction in any medium, provided the original work is properly credited.

\section{REFERENCES}

1. Chambrone LA, Chambrone L. Tooth loss in wellmaintained patients with chronic periodontitis during long-term supportive therapy in Brazil. J Clin Periodontol 2006; 33: 759-764.

2. Botelho MA, Rao VS, Carvalho CB, Bezerra-Filho JG, Fonseca SG, Vale ML, Montenegro D, Cunha F, Ribeiro $R A$, Brito GA. Lippia sidoides and Myracrodruon urundeuva gel prevents alveolar bone resorption in experimental periodontitis in rats. $J$ Ethnopharmacol 2007; 113: 471-478.

3. Tu HP, Fu MM, Kuo PJ, Chin YT, Chiang CY, Chung CL, $\mathrm{Fu} E$. Berberine's effect on periodontal tissue degradation by matrix metalloproteinases: an in vitro and in vivo experiment. Phytomedicine 2013; 20: 12031210.

4. Ke XJ, Lei L, Li H, Li HX, Yan FH. Manipulation of necroptosis by Porphyromonas gingivalis inperiodontitis development. Mol Immunol 2016; 77: 8-13.

5. Cobb CM. Clinical significance of non-surgical periodontal therapy: an evidence-based perspective of scaling and root planning. J Clin Periodontol 2002; 29: 22-32.

6. Christgau M, Moder D, Hiller KA, Dada A, Schmitz G, Schmalz G. Growth factors and cytokines in autologous platelet concentrate and their correlation to periodontal

Trop J Pharm Res, March 2017; 16(3): 594 
regeneration outcomes. J Clin Periodontol 2006; 33: 837-845.

7. Chen HY, Wu JX. The research progress of periodontitis. Med Recapitul 2013; 19: 1037-1039.

8. National Institute of Health, USA. Public health service policy on humane care and use of laboratory animals; 2002.

9. Kimura S, Nagai A, Onitsuka T, Koga T, Fujiwara T, Kaya $H$, Hamada S. Induction of experimental periodontitis in mice with porphyromonas gingivalis-adhered ligatures. $J$ Periodontol 2000; 71: 1167- 1173.

10. Pan $Q R$, Lu FL, Song N, Huang SG. Effect of total glucosides of paeony on serum levels of $\lg G 1$ and IgG2a in mouse model of periodontitis. Chin $J$ Pathophysiol 2011; 27: 1462-1466.

11. Peng $W$, Han T, Xin WB, Zhang XG, Zhang $Q Y$, Jia $M$, Qin LP. Comparative research of chemical constituents and bioactivities between petroleum ether extracts of the aerial part and the rhizome of Atractylodes macrocephala. Med Chem Res 2011; 20: 146-151.

12. Adesokan AA, Akanji MA, Yakubu MT. Antibacterial potentials of aqueous extract of Enantia chlorantha stem bark. Afr J Biotechnol 2007; 6: 2502-2505.

13. Chen YH, Zhu FY, Ren XB, He HB. New development of study on the animal model of periodontitis. Chin J Prac Stomatol 2011; 9: 117-121.

14. Sun JY, Li DL, Dong Y, Zhu CH, Liu J, Li JD, Zhou T, Gou JZ, Li A, Zang WJ. Baicalin inhibits toll-like receptor 2/4 expression and downstream signaling in rat experimental periodontitis. Int Immunopharmacol 2016; 36: 86-93.
15. Hajishengallis G. Periodontitis: from microbial immune subversion to systemic inflammation. Nat Rev Immunol 2015; 15: 30-44.

16. Samejima V, Ebisu S, Okada H. Effect of injection with Eikenella corrodens on the progression of ligature induced periodontitis in rats. J Period Res 1990; 25: 308-315.

17. Pihlstrom BL, Michalowicz BS, Johnson NW. Periodontal diseases. Lancet 2005; 366: 1809-1820.

18. Bai Y, Wei Y, Wu L, Wei J, Wang X, Bai Y. C/EBP $\beta$ Mediates Endoplasmic Reticulum Stress Regulated Inflammatory Response and Extracellular Matrix Degradation in LPS-Stimulated Human Periodontal Ligament Cells. Int J Mol Sci 2016; 17:385.

19. Wu YY, Liu HC. Relationship between TNF- $\alpha, I L-1 \beta$ \& IL6 and diabetes mellitus \& periodontitis. Chin J Geria Dent 2011; 9:117-121.

20. Chin PY, Dorian CL, Hutchinson MR, Olson DM, Rice KC, Moldenhauer LM, Robertson SA. Novel Toll-like receptor-4 antagonist (+)-naloxone protects mice from inflammation-induced preterm birth. Sci Rep 2016; 6:36112.

21. Meikle MC, Atkinson SJ, Ward RV, Murphy G, Reynolds JJ. Gingival fibroblasts degrade type I collagen films when stimulated with tumor necrosis factor and interleukin 1: evidence that breakdown is mediated by metal loproteinases. J Period Res 1989; 24: 207-213.

22. Baker PJ, Dixon M, Evans RT, Dufour L, Johnson $E$. $C D 4^{+} T$ cells and the proinflammatory cytokines gamma interferon and interleukin- 6 contribute to alveolar bone loss in mice. Infect Immu 1999; 67: 2804- 2809. 